\title{
KRITERIJI ODREĐIVANJA I SISTEMATIZACIJA PRAVNIH NAČELA U VISOKOM OBRAZOVANJU I ZNANOSTI
}

Cilj rada jest istražiti na temelju kojih kriterija sistematizirati te uopće odrediti pravna načela "sveučilišnog prava i prava znanstvenih organizacija". Prilikom njihova istraživanja polazi se od dviju dihotomija pravnog sistema: dihotomije otvorenosti i zatvorenosti te dihotomije odnosa činjenica $i$ vrijednosti. Obje dihotomije, prikazane u kontekstu različitih teorijskih pristupa, upućuju na nemogućnost odredivanja općeprihvaćenih kriterija ne samo za sistematiziranje pravnih načela nego i za njihovo razlikovno određivanje u odnosu na pravna pravila, kao i u odnosu na načela $i$ standarde čija se pravna obvezatnost $i$ u teoriji i u praksi nerijetko dovodi u pitanje. Polazeći od toga da je bitno obilježje pravnih načela to što posreduju temeljne vrijednosti te obilježje sadržajne i brojčane otvorenosti, u drugom dijelu rada iznosi se podjela pravnih načela "sveučilišnog prava $i$ prava znanstvenih organizacija" s obzirom na vrstu pravnih izvora te sobzirom na stupanj njihove normativne konkretizacije (tzv. izričita i neizričita pravna načela).

Ključne riječi: jamstvo autonomije, dihotomija, izričita i neizričita pravna načela, normativna konkretizacija

\section{UVOD}

U teoriji postoji određena suglasnost da su pravna načela najviše odnosno temeljne vrijednosti kojima pravni sistem služi. U primijeni se nerijetko pokazuje kako ne postoji jednoznačno tumačenje koje su to vrijednosti te što su to

* Dr. sc. Ksenija Grubišić, izvanredna profesorica Pravnog fakulteta u Zagrebu, Trg Republike Hrvatske 14, Zagreb; ksenija.grubisic@pravo.hr;

ORCID ID: orcid.org/0000-0003-2464-1438 
pravna načela. Stoga kada nastanu opravdane okolnosti za određivanje pravnih načela za pojedini dio pravnog sistema koji još nije sistematiziran, kao što je područje visokog obrazovanja i znanosti, prethodno bi bilo dobro razjasniti ili, što se čini realnijim, preciznije objasniti početnu odabranu perspektivu za takvo tumačenje koja je, dobrim dijelom, uvjetovana tim novonastalim okolnostima.

Možda nepotpuna, ali jedna sigurno ispravna perspektiva jest ako se pravna načela određuju na temelju Ustava i zakona. Od početka bolonjske reforme, koja je u Hrvatskoj počela prije gotovo dvadeset godina, doneseno je mnogo zakona koji uređuju područje visokog obrazovanja i znanosti. Osim temeljnog Zakona o znanstvenoj djelatnosti i visokom obrazovanju ${ }^{1}$ riječ je o Zakonu o potvrđivanju konvencije o priznavanju visokoškolskih kvalifikacija u području Europe $^{2}$, Zakonu o studentskom zboru i drugim studentskim organizacijama ${ }^{3}$, Zakonu o akademskim i stručnim nazivima i akademskom stupnju ${ }^{4}$, Zakonu o priznavanju inozemnih obrazovnih kvalifikacija ${ }^{5}$, Zakonu o Hrvatskoj zakladi za znanost $^{6}$, Zakonu o osiguravanju kvalitete $\mathrm{u}$ znanosti i visokom obrazovanju $\mathrm{u}^{7}$ te Zakonu o Hrvatskom kvalifikacijskom okviru. ${ }^{8}$ Tim zakonima, u odnosu na vrijeme prije reforme, uređuju se djelomično drukčije postojeći, ali i stvaraju novi društveni odnosi. To ujedno znači da se iz tih zakona mogu iščitati određena pravna načela, a jedan od ciljeva ovog rada jest istražiti je li samo riječ o stvaranju novih pravno relevantnih društvenih odnosa uz primjenu postojećih pravnih načela, poštuju li se tim novim pravnim normama ta postojeća pravna načela u području visokog obrazovanja i znanosti te mogu li se iščitati i neka nova, koja sada dodatno uvjetuju normativno uređenje istaknutog područja. Naime, činjenica postojanja novih zakona otvara potrebu za hijerarhijskom i znanstvenom sistematizacijom. Jedna od važnijih, ako ne i najvažnija, pretpostavka uspješne sistematizacije određenog dijela pravnog sistema pretpostavlja upravo istraživanje pravnih načela za to područje. U istraživanju ovog dijela

1 Narodne novine, br. 123/2003, 105/2004, 174/2004, 2/2007 - Odluka USRH, 46/2007, 45/2009, 63/2011, 94/2013 i 139/2013, 101/2014 - Odluka i Rješenje USRH, 60/2015 - Odluka USRH, 131/2017 (dalje u tekstu: ZZDVO).

2 Narodne novine, Međunarodni ugovori, br. 9/2002 i 15/2002 (dalje u tekstu: ZPKPVKPE).

3 Narodne novine, br. 71/2007 (dalje u tekstu: ZSZDSO).

4 Narodne novine, br. 107/2007 i 118/2012 (dalje u tekstu: ZASNAS).

5 Narodne novine, br. 158/2003, 198/2003, 138/2006, 124/2009, 45/2011 (dalje u tekstu: ZPIOK).

6 Narodne novine, br. 117/2001, 45/2009, 92/2010 i 78/2012 (dalje u tekstu: ZHZZ).

7 Narodne novine, br. 45/2009 (dalje u tekstu: ZOKZVO).

8 Narodne novine, br. 22/2013 i Odluka USRH, br. 4l/2016 (dalje u tekstu: ZHKO). 
pritom je nužno uvrstiti načela upravnog prava u koje nedvojbeno pripada područje visokog obrazovanja i znanosti. Međutim, mnoštvo novih zakona te drugih propisa dovelo je do nastajanja složenijih institucionalnih struktura, novih pravnih ustanova, drugim riječima do ostvarivanja mnogih kriterija koji opravdavaju pokušaj sistematiziranja istaknutog dijela kao samostalne pravne grane. ${ }^{9}$ Posebice ako se uzme u obzir i postojanje pravnih načela koja vrijede samo za područje visokog obrazovanja i znanosti, što onda dodatno opravdava svako nastojanje za sistematizacijom ovog istaknutog, a na temelju ostvarenih određenih kriterija i kao samostalnog, dijela pravnog sistema. ${ }^{10}$

Za područje visokog obrazovanja i znanosti upotrebljavam izraz "sveučilišno pravo i pravo znanstvenih organizacija”. Razlog tome jest, jednim dijelom, u samim subjektima istaknutog dijela pravnog sistema - sveučilištu i sveučilišnim visokim učilištima - čija je zadaća i ustroj posebno obilježen načelom specifičnim za područje visokog obrazovanja i znanosti - načelom autonomije. Pritom smatram posebno važnim podsjetiti kako je ustavno i/ili zakonsko utemeljenje i određivanje autonomije posljedica ne samo pravnog nego i višestoljetnog teorijskog - uglavnom filozofskog - promišljanja uloge i zadaće sveučilišta kao visokoobrazovne ustanove od njegova osnivanja do danas. ${ }^{11}$ Drugim riječima, to znači da autonomnost ustroja, znanstvenog, nastavnog i umjetničkog stvaralaštva kao bitnog obilježja sveučilišta i sveučilišnih visokih učilišta predstavlja nasljeđe ne samo pravnih nego i u širem smislu shvaćenih tradicionalnih vrijednosti koje, formulirane na razini ustavnog jamstva, razlikuju tu vrstu visokih učilišta od drugih (nesveučilišnih) visokih učilišta i znanstvenih organizacija. Također, to čini opravdanim pretpostaviti da osim ustavnog jamstva autonomije, i pojedina druga načela koja određuju pravne norme "sveučilišnog prava i prava znanstvenih organizacija" nikako ne predstavljaju samo svojevrsnu sublimaciju iščitanu iz pravnih normi, nego imaju svoju historijsku i teorijsku utemeljenost i opravdanost.

9 Vidi Harris, J. W., Law and Legal Science, Oxford University Press, New York, 2007., str. 12 i dalje. Vidi više i u: Grubišić, K., Sistematizacija pravnih normi u visokom obrazovanju i znanosti u Republici Hrvatskoj, Zbornik Pravnog fakulteta u Zagrebu, vol. 67, br. 3-4, 2017., str. 565 - 599.

10 Više o sistematizaciji unutar pravnih područja u: Ruiter Dick, W. P., Legal Institutions, Kluwer Academic Publishers, Dordrecht, 2010., str. 70 i dalje.

11 Mislim na tumačenje autonomije kod Kanta, Schellinga, Humboldta, Nietzschea i dr. Više o tumačenju autonomije u kontekstu bolonjske reforme u: Liessmann, K. P., Teorija neobrazovanosti: zablude društva znanja, Naklada Jesenski i Turk, Zagreb, 2008. str. 43 i dalje. 
Osim navedenog, pravno uređenje postojećih te stvaranje novih pravno relevantnih društvenih odnosa uvjetovano je i time što je donošenje niza tih novih zakona nastalo $\mathrm{u}$ istaknutom vremenu obilježeno i procesom europeizacije, što je ujedno značilo i znači normativno povezivanje s određenim vrijednostima koje se ne iščitavaju samo iz nacionalnih pravnih poredaka, već one predstavljaju i "zajedničke" vrijednosti objedinjene te, više ili manje, prepoznatljive kroz izraze "Europski prostor visokog obrazovanja", "Europski istraživački prostor", "Kvalifikacijski okvir Europskog prostora visokog obrazovanja”, "Europski kvalifikacijski okvir za cjeloživotno učenje”, a posredno i "Europski upravni prostor". Stoga u daljnjem utvrđivanju pravnih načela osim pozitivnopravnih propisa kao polazišnu perspektivu treba uzeti u obzir i naznačen proces europeizacije, koji zahtijeva da se uz teorijske, historijske, pozitivnopravne vrijednosti koje uvjetuju normiranje područja visokog obrazovanja i znanosti istraže i europske vrijednosti u mjeri u kojoj su one primijenjene u novim zakonima kao obvezujuća (pravna) načela ili utječu na primjenu pravnih normi.

I konačno, pravnim načelima kao vrijednostima štiti se javni, odnosno opći interes, što je posebno uočljivo u području javnog prava i javnih ustanova kao što su visoka učilišta odnosno znanstvene organizacije. Tim općim interesima nužno se štite određene pravne, akademske, europske vrijednosti kao javne vrijednosti svojstvene području visokog obrazovanja i znanosti. Traženje odgovora na pitanje na koji način se one štite, odnosno štite li se putem pravnih načela te koji je njihov hijerarhijski "status", zahtijeva da se prethodno odgovori na ranije opisane ciljeve rada koji se sada mogu sažeti u jednu rečenicu: istražiti pravna načela koja određuju "sveučilišno pravo i pravo znanstvenih organizacija”.

\section{DVIJE DIHOTOMIJE PRAVNOG SISTEMA}

\section{Općenito}

Kod istraživanja pravnih načela pokazuje se sva kompleksnost pravnog sistema. To je uočljivo i kod određivanja načela pravnog sistema u cjelini ili, u ovom slučaju, kod određivanja načela pojedine (dijela) pravne grane. Pravna načela su izraz koji nema općeprihvaćeno tumačenje ni u samom značenju te riječi, ni u tumačenju razlikovnih obilježja u odnosu na pravna pravila, ni u razumijevanju "stupnja" njihove obvezatnosti, pa samim time i hijerarhijske odredivosti u pravnom sistemu, na što upozoravaju mnogi autori. ${ }^{12}$ Ovisno o

12 Jedno od temeljnih pitanja koje, primjerice, postavlja Dworkin, ali i drugi, što ćemo nadalje pokazati, jest što su to načela i koja su načela pravna i pravno obvezujuća 
različitim pristupima svrstanim u filozofiju prava, opću teoriju prava, sociologiju prava odnosno pravnu znanost, kao i metodama kako se njihova obilježja tumače, iščitavaju se različita relevantna pitanja za koja se vjeruje da ponajbolje vode odgovorima na sve istaknute dvojbe. Kao razlog tome navodim dvije dihotomije koje obilježavaju pravni sistem: dihotomija zatvorenosti $i$ otvorenosti te dihotomija odnosa činjenica $i$ vrijednosti. Njihovo supostojanje jasno pokazuje kompleksnost pravnog sistema, pri čemu pravna načela imaju presudnu ulogu u njihovu otkrivanju. Naime, pravni sistem podložan je sistematskom tumačenju (hijerarhijskom i znanstvenom), dogmatskom, jezičnom, teleološkom, te drugim pravnim i teorijskim tumačenjima iz kojih proizlazi razumijevanje prava kao pravnog poretka, kao pravnog sistema, ali i razumijevanje prava kao metafizičkog sistema, kao socijalnog, vremenskog, kulturnog, vrijednosnog, kao podsistema sistema društva itd. Ono što je zajedničko svim tim pristupima jest da daju, neposredno ili posredno, odgovore u kojima su pretpostavljena navedena dihotomijska obilježja. Ono po čemu se razlikuju jest relevantnost koju tim obilježjima dodjeljuju za oblikovanje pravnog sistema, a onda i za određivanje pravnih načela. S obzirom na to da su, samim time, ta dihotomijska obilježja primjetna i u području "sveučilišnog prava i prava znanstvenih organizacija”, treba ih uzeti u obzir u daljnjem istraživanju.

\section{Otvorenost i zatvorenost}

Zatvorenost kao obilježje pravnog sistema osobito je naglašena kod normativističke teorije koja pravni sistem tumači kao ukupnost pravnih normi koje čine pravni poredak u kojem je mjerodavan samo hijerarhijski odnos normi i zakonitost. Naime, ishodišni pojam razumijevanja jest pravna norma čije se značenje tumači isključivo putem ciljeva/vrijednosti koje je normotvorac htio postići normama. Stoga se i pravo u smislu pravnog poretka ponajviše razumije kao skup normativnih tekstova (ustava, zakona i drugih propisa), odnosno jezičnih iskaza ili, u širem smislu, koje uključuje i tumačenje svih normativnih tekstova te “pravnog konstituiranja” kao razvijanja neizraženih normi. ${ }^{13}$ Tako je za Kelsena pravni poredak sistem nadređenih i podređenih pravnih normi, pri čemu je niža norma proizvedena na način koji viša norma propisuje koje tijelo treba donijeti

te što znači primjenjivati ih. Vidi Dworkin, R., Shvaćanje prava ozbiljno, KruZak, Zagreb, 2003., str. 11.

13 Vidi Guastini, R., Sintaksa prava, Naklada Breza, Zagreb, 2016., str. 213. O tumačenju prava kao institucionalnom normativnom poretku vidi više u: MacCormick, N., Institutions of Law: An Essay in Legal Theory, Oxford University Press, New York, 2009., str. 15 i dalje. 
nižu normu ili sadržaj norme koje to tijelo treba donijeti. ${ }^{14}$ Očito je da ovakvo tumačenje zagovara samo hijerarhijsko vrednovanje više norme u odnosu na nižu normu, ciljevi/vrijednosti se iščitavaju samo iz norme, dok "vanjski” ciljevi u smislu društvenih, etičkih, političkih vrijednosti nisu mjerodavni.

Međutim, postoje tumačenja da pravo nije samo ukupnost pravnih normi, što znači da ishodište tumačenja nije samo u pravnoj normi kao kod normativista, nego i u pravnom odnosu i pravnim vrijednostima. Pritom, pravo se razumije kao pravni poredak tumačen kao hijerarhijski sistem pravnih normi, ali istodobno i kao uređen sistem koji podrazumijeva logički dosljedne i vrijednosno povezane norme, odnosno potpunu cjelinu. ${ }^{15} \mathrm{~A}$ upravo potonja obilježja pravnog sistema otkrivaju i pojedina obilježja njegove otvorenosti. Primjerice, logička dosljednost pretpostavlja odsutnost antinomija između normi, što je teško ostvarivo s obzirom da se norme donose i mijenjaju u različitim vremenima, pod utjecajem različitih "vanjskih" okolnosti i od različitih tijela. Stoga se logička dosljednost u tumačenju normi nastoji osigurati pravnim načelima kao što su kao lex posterior, lex specialis, lex superior ${ }^{16}$, pri čemu je korisno podsjetiti da se istaknuta načela smatraju općeprihvaćenim, obvezujućim načelima i kada izričito nisu sadržaj pravne norme. Osim toga, potonja pravna načela vrijede za cijeli pravni sistem, a ne za pojedinu granu, te omogućuju, među ostalim, rješavanje sukoba hijerarhije nastalog izmjenama pravnih normi pod utjecajem vanjskih okolnosti. Na taj način ona ujedno doprinose rješavanju dihotomije zatvorenosti i otvorenosti pravnog sistema.

U kontekstu iznesenog smatram važnim izdvojiti još dvije pozitivističke pravne škole koje osim zatvorenosti uzimaju u obzir pojedina obilježja otvorenosti na način kojim vjerodostojno upućuju na slojevitost tumačenja pravnog sistema, pa samim time i pravnih načela koja u tumačenju pravnih normi imaju presudnu ulogu. To su sociološka i integrativna škola. Obje teorije polaze od pretpostavke da se značenje pravnih normi treba tumačiti iz ciljeva/vrijednosti sadržanih u samoj pravnoj normi, ali koje ipak uključuju i ciljeve koji odgovaraju potrebama i vrijednostima društva neovisno o tome što su pojedinom normom htjeli postići normotvorci. U tom smislu za sociološke teorije pravni sistem nije samo sistem pravnih normi već i pravnih odnosa na koji utječu društvene, ekonomske, kulturne, vremenske raznolikosti, ciljevi i vrijednosti, što drugim riječima znači da na pravni sistem osim formalnih izvora utječu "vanjski", materijalni izvori prava. ${ }^{17}$

\footnotetext{
14 Vidi Kelsen, K. Opća teorija normi, Naklada Breza, Zagreb, 2015., str. 275 i 277.

15 Vidi Guastini, op. cit. u bilj. 13, str. 215.

16 Guastini, op. cit. u bilj. 13, str. 217.

17 Više o materijalnim izvorima prava u: Visković, N., Teorija države i prava, Birotehnika
} 
Za primjer takvog pristupa uzimam Luhmannovu teoriju. Naime, on tumači kako jedinstvo pravnog sistema ne čini samo ukupnost pravnih normi, jedinstvo nekog teksta ili konzistentnost neke množine tekstova. Pravo tumači u kontekstu svoje teorije sistema (prava) koja opisuje kako nešto proizvodi plastite granice u odnosu spram okolnog svijeta. U tom smislu za njega pravo nije samo pravni poredak nego "podsistem sistema društva"18 , koji još naziva "operativno zatvoreni autopojetični sistem prava”. To drugim riječima znači da se jedinstvo pravnog sistema može razumijevati samo ako se pravo tumači i kao socijalni sistem. ${ }^{19}$ Također, čini se ispravnim zaključiti kako se u temelju tako shvaćenog jedinstva prepoznaju dihotomijska obilježja otvorenosti i zatvorenosti pravnog sistema.

Integralne teorije osim pravne norme i pravnih odnosa kao dio pravnog sistema ističu i pravne vrijednost $i^{20}$ kao jedan od temeljnih dijelova pravnog sistema, što dodatno pokazuje složenost prava, ali i potrebu da se ono istražuje različitim metodološkim pristupima (dogmatskim, historijskim, filozofskim, sociološkim), koji se nužno ne bi trebali isključivati već međusobno nadopunjavati. ${ }^{21}$ Vrijednosna povezanost kao obilježje pravnog sistem u idealnom bi smislu trebala značiti, među ostalim, da su sve pravne norme svedive na jedno načelo ili vrijednost ili jedan odnos međusobno dosljednih načela ili vrijednosti. ${ }^{22}$ Kao što je već naznačeno, takva pretpostavka da bi postojeće norme u određenom pravnom poretku imale zajednički vrijednosni temelj predstavlja neodrživ ideal koji se, naravno, nastoji ostvarivati putem pravnih načela. Naime, iako se može uzeti kao općeprihvaćena odredba da pravna načela iskazuju temeljne vrijednosti kojima pravni sistem služi, razlog neodrživosti jest činjenica postojanja njihova mnoštva, što nužno otvara i problem sukoba i problem njihova hijerarhijskog sistematiziranja te, kao što upozoravaju pojedini teoretičari, primjene. Razlog tome nalazi se također $\mathrm{u}$ dihotomiji otvorenosti i zatvorenosti, ali i u iskustvenim metodološkim pristupima bitno predodređenima, kao što ću nadalje pokazati, drugom dihotomijom.

$\mathrm{Na}$ temelju navedenog, za sada se može ustvrditi da pravna načela ponekad jesu, a ponekad nisu izričit sadržaj pravne norme, ali su bez obzira na to - veći dio njih - općeprihvaćena u gotovo svakom pravnom sistemu. Pritom je riječ i o načelima koja je odredila pravna znanost i pravna praksa kao, primjerice, jedno od prije spomenutih načela lex specialis. Osim toga, postoje pravna načela kojima

CDO, Zagreb, 2001., str. 133 i dalje.

18 Vidi Luhmann, N., Pravo društva, Naklada Breza, Zagreb, 2014., str. 15.

19 Vidi Luhmann, op. cit. u bilj. 18, str. 50. i dalje.

20 Visković, N., Teorija prava, Split, 1985., str. 37.

21 Visković, op. cit. u bilj. 20, str. 34.

22 Vidi Guastini, op. cit. u bilj. 13, str. 216. 
se žele zaštititi određene pravne vrijednosti (npr. zakonitost, pravna sigurnost), kao i ona kojima se žele zaštititi vrijednosti koje nisu samo pravne vrijednosti, kao npr. načelo slobode, jednakosti, ravnopravnosti itd. Štoviše, za određivanje njihova društvenog značenja nezaobilazno je njihovo filozofsko ili šire teorijsko razumijevanje, kao svojevrsna pretpostavka njihove pravne primjene posredstvom načela. I kod takvih načela pojedina su izrečena neposredno kroz pravnu nor$\mathrm{mu}$, nerijetko u Ustavu, a pojedina su posljedica različitih pravnih tumačenja.

Iako ću se u radu uglavnom koristiti normativističkim pristupom u smislu propitivanja načela zakonitosti kao hijerarhijskog sistema usklađenosti više i niže norme, pri čemu pod višim normama ovdje mislim, među ostalim, na pravna načela koja uglavnom proizlaze iz Ustava i zakona, čini se također opravdanim pretpostaviti da za sveobuhvatnije određenje načela u dijelu pravnog sistema koji još nije sistematiziran ne treba isključiti ni jedan od opisanih pristupa odnosno škola. Naime, sve ove "vrste" načela prisutne su i u području "sveučilišnog prava i prava znanstvenih organizacija". Poneka od njih su izričito, a poneka nisu, sadržana u pravnoj normi Ustava ili/i zakona. Također, neka od njih štite pojedine pravne vrijednosti, a neke i šire, društvene, koje djelomično obilježene i uvjetovane spomenutim procesom europeizacije u posljednjem desetljeću nisu samo nacionalne. Stoga u području visokog obrazovanja i znanosti postojanje takvih vrijednosti i načela koji promiču šire društvene vrijednosti stvaranjem novih pravno relevantnih društvenih odnosa dodatno unaprijed opravdava zahtjev za istraživanjem materijalnih izvora tih normi, u smislu istraživanja koje će vrijednosti prevladati i postati izvorom pravnog normiranja. ${ }^{23}$

\section{3. Činjenice i vrijednosti}

Pravna norma uvijek je sredstvo za ostvarivanje nekih ciljeva odnosno vrijednosti. U tome će se sve pravne škole složiti. Kelsen, primjerice, kaže kako pravna norma koja postavlja određeno ponašanje kao trebano konstituira neku vrijednost. ${ }^{24}$ Kao što sam uvodno spomenula, u hijerarhiji pravnih normi na prvom mjestu su načela kao najviše pravne norme jer iskazuju temeljne vrijednosti kojima pravni sistem služi te su stoga presudna za usmjeravanje stvaranja, tumačenja i primjene svih ostalih pravnih normi. ${ }^{25}$ Međutim, kontekst dosadašnjih razmatranja dostatno pokazuje da takve tvrdnje nisu uopće jednoznačne jer otvaraju

23 Visković, op. cit. u bilj. 17, str, 136 - 137.

24 Kelsen, op. cit. u bilj. 14, str. 73, 145.

25 Vidi Visković, op. cit. u bilj. 17, str. 253; Pavčnik, M., Teorija prava, Založba, Ljubljana, 2011., str. 123 i dalje; Guastini, op. cit. u bilj. 13, str. 78 i dalje. 
niz potpitanja poput: jesu li sva načela hijerarhijski najviše pravne norme, jesu li načela kao temeljne vrijednosti samo ona izražena kroz pravnu normu, je li moguća njihova jednoznačna hijerarhijska odredivost i što je u slučajevima "sukoba" načela? Relevantnost ovakvih pitanja na određeni način potvrđuje dihotomiju otvorenosti i zatvorenosti pravnog sistema s većim naglaskom na obilježje otvorenosti u kojem se prepoznaju društvene, kulturne i druge vrijednosti koje su izričito ili ne, posredstvom pravnih načela, sadržane ili protumačene, $u$ pravnim normama pravnog sistema. ${ }^{26}$

Naime, zatvorenost pravnog sistema pokazuje neka obilježja idealnosti prava, čime ujedno upućuje i na sličnost s moralom, kao što su zakonitost, pravna sigurnost, logička i vrijednosna cjelovitost i dosljednost. Otvorenost, pak, pokazuje iskustvenu raznolikost tih istih obilježja pravnog sistema. Štoviše, sve spomenute škole, pa čak i čista teorija prava, imaju za pretpostavku iskustvenu metodološku perspektivu u pokušaju određivanja i prepoznavanja pravnih načela. A time se pokazuje očitom i druga dihotomija pravnog sistema, a to je odnos činjenica i vrijednosti.

Dihotomija odnosa činjenica i vrijednosti pokazuje neraskidivu povezanost prava s moralom najočitiju, naravno, kod tumačenja načela jer je i u moralu i u pravu imanentno nastojanje da se načela djelovanja i načela normiranja ne utemeljuju samo na iskustvenoj raznolikosti, nego da su obilježeni i neovisnošću od takve promjenjivosti. Ipak, iako u etici postoje tumačenja o autonomnom načelu djelovanja koje je utemeljio Kant, pri čemu se pod autonomnim djelovanjem misli na moralnu slobodu kao djelovanje oslobođeno svih iskustvenih raznolikosti, u pravu takvog načela nema jer je ono uvijek uvjetovano i iskustvom. $\mathrm{Na}$ to je upozorio i sam Kant. Iako je za njega pojam prava sistem proizašao iz uma, što znači da je riječ o čistom umnom pojmu, on ujedno tumači i da je riječ o pojmu utemeljenom u praksi. To, pak, znači da bi sistem prava u svojoj podjeli trebao uzeti u obzir svu iskustvenu raznolikost svih slučajeva primjene, što je nemoguće, pa je zato samo riječ o počelima (a ne o načelima). ${ }^{27} \mathrm{U}$ skladu s tim, za pravni sistem Kant kaže da je skup zakona za koje je moguće (samo) izvanjsko zakonodavstvo, ali u kojima je potrebno ipak utvrditi nepromjenjiva

26 Posebno kod tumačenja ustavnih normi pojedini teoretičari, primjerice Häberle, naglašavaju kulturnoznanstvenu perspektivu tumačenja Ustava jer je riječ o normativnom aktu koji je ujedno i "generacijski ugovor" uvjetovan i utemeljen na pojedinim kulturnim vrijednostima. Više u: Häberle, P., Ustavna država, Politička kultura, Zagreb, 2002., str. 22 i dalje.

27 U predgovoru djela Metafizika ćudoređa Kant tumači zašto je kod pravnog nauka kao dijela nauka o ćudoređu riječ samo o istraživanju metafizičkih počela pravnog nauka. Kant, I., Metafizika ćudoređa, Matica hrvatska, Zagreb, 1999., str. 3. [6:205] 
načela za svekoliko pozitivno zakonodavstvo jer "pravni nauk koji se temelji samo na iskustvu jest glava koja je možda lijepa, ali - na žalost! - nema mozga". ${ }^{28}$ Kao primjere Kant navodi nekoliko načela na temelju kojih je uopće moguće utemeljenje države. Naziva ih "čistim umnim načelima vanjskog ljudskog prava”, a to su: sloboda svakog člana društva, kao čovjeka; jednakost svakoga sa svakim te samostalnost svakog člana jedne političke zajednice kao građanina. ${ }^{29}$ U skladu s njima Kant izriče i opće načelo prava: "Pravo je ograničenje slobode svakoga na uvjete mogućnosti slaganja sa slobodom svakoga drugog, ukoliko je ova moguća prema općem zakonu, a javno pravo je skupina izvanjskih zakona, koji čine mogućim jedno takvo opće slaganje”. ${ }^{30}$

Iako ovakve misli mogu ostaviti dojam pretjerane teorijske refleksije, treba uzeti u obzir da ne možemo znati uskraćuje li zanemarivanje takvog puta promišljanja uvid u obuhvatnije razumijevanje pravnih načela, pa i pravnog sistema u cjelini. Ovdje bi samo za usporedbu s citiranim Kantovim općim načelom prava citirala čl. 16. st. 2. Ustava Republike Hrvatske (dalje u tekstu: Ustav), za koji se može reći na temelju tumačenja Ustavnog suda Republike Hrvatske (dalje u tekstu: USRH) da predstavlja, kao što ću kasnije pokazati kod podjele načela "sveučilišnog prava i prava znanstvenih organizacija", jedinu mjeru granice zaštite ustavnog jamstva autonomije sveučilišta, odnosno načela akademskih sloboda. Članak 16. Ustava ${ }^{31}$ glasi:

Sloboda i prava mogu se ograničiti samo zakonom da bi se zaštitila sloboda i prava drugih ljudi te pravni poredak, javni moral $i$ zdravlje.

Svako ograničenje slobode ili prava mora biti razmjerno ${ }^{32}$ naravi potrebe za ograničenjem u svakom pojedinom slučaju.

Nadalje, iako su u primjeni ta "čista umna načela vanjskog ljudskog prava" kao i "opće načelo prava" uvjetovani s objema istaknutim dihotomijama pravnog sistema, to ne umanjuje njihovu važnost da je riječ o pravnim načelima koja su i u materijalnom i formalnom smislu hijerarhizirana na razinu gotovo općeprihvaćenih ustavnih temeljnih vrednota, jamstava i načela.

28 Kant, op. cit. u bilj. 27, str. 26. [6:230]

29 Vidi Kant, I., Pravno-politički spisi, Politička kultura, Zagreb, 2000., str. 75.

30 Kant, op. cit. u bilj. 29, str. 74. Na drugom mjestu Kant za opće načelo prava piše: "Pravično je svako djelovanje koje dopušta ili čija maksima dopušta da po općem zakonu sloboda svačijeg htijenja supostoji sa svačijom slobodom itd., u: Kant, op . cit. u bilj. 27, str. 27. [6:231]. Primjena ovog općeg načela prava omogućuje dolaženje do određenih normi koje nisu proizvod “čistog” uma pa nemaju opće važenje, već samo primjenu na određeno društvo, vrijeme i narod.

31 Ustav RH, Narodne novine, br. 56/1990, 135/1997, 28/2001, 76/2010 i 5/2014.

32 Istaknula autorica. 
Osim navedenog, pitanja i posljedice koje proizlaze iz takva razmišljanja utjecala su na kasnija pravnoteorijska mišljenja te su i danas itekako relevantna. Prije svega mislim na Kantovo pitanje o tome mogu li se pravna načela tumačiti kao nepromjenjivi umni principi, što nužno doprinosi obilježju zatvorenosti te ranije spomenutoj logičkoj i vrijednosnoj dosljednosti, ili je njihova obvezatnost i odredivost ponajviše uvjetovana iskustvenim raznolikostima. Naime, ovakvo promišljanje načela kao "čistih" umnih principa nastalih neovisno o iskustvu, ali s primjenom na iskustvo, upućuju na određena obilježja autonomnosti prava očitovanog upravo kroz postojanje i primjenu tih načela koja kao, više ili manje, protumačeni umni principi uvjetuju iskustvo kroz primjenu: na to je upozoravao Kant, a pod njegovim utjecajem na to su upozoravale i upozoravaju mnoge pravne škole, na to je upozoravao Kelsen, ali također Luhmann, Dworkin i dr. Podsjećam ovdje na ranije iznesenu Luhmannovu tezu o pravu kao “operativno zatvorenom autopojetičnom sistemu". Za Dworkina, pak, pravo nije samo skup pravnih normi jer se ono uvijek odnosi i na ono što treba biti, na pravedno po sebi: “Očito svaka teorija utemeljena na pravu mora pretpostaviti prava koja nisu samo tvorevina svjesnoga zakonodavstva ili izričitog društvenog običaja nego su i neovisan temelj za prosudbu zakonodavstva i običaja". ${ }^{33} \mathrm{U}$ podlozi ovakvog tumačenja nalazi se i Kantov dualizam moralnosti i legalnosti, koji kod Dworkina nije tako odvojen kao kod drugih pozitivnopravnih škola.

Utjecaj na Kelsena vidljiv je već iz samog naziva njegove teorije. Tako snažan pojam "čista" 34 u filozofiji je utemeljio upravo Kant. Tim pojmom, na kojem je utemeljio svoj kriticizam, upućivao je na transcendentalno (uvjetovano) obilježje naše moći spoznavanja koje ujedno u praktičnom djelovanju predstavlja mogućnost autonomnog moralnog djelovanja oslobođeno svih iskustvenih raznolikosti vođeno umnim načelom (kategoričkim imperativom). ${ }^{35} \mathrm{Za}$ Kelsena se ne može tvrditi da je u tom smislu "strogo" i dosljedno preuzeo pojam "čist" za naziv te utemeljenje svoje teorije, ali se može reći da mu je bila namjera i kod tumačenja pravnih načela upozoriti na obilježje zatvorenosti, koje se samo djelomično može poistovjetiti s Kantovim tumačenjem autonomnosti. ${ }^{36}$ Osim toga, upravo dualizam činjenica i vrijednosti koje je također utemeljio Kant ${ }^{37}$

33 Dworkin, op. cit. u bilj. 12, str. 194.

34 Njem. rein.

35 Vidi Kant, I., Kritik der reinen Vernunft 1, Frankfurt am Main, 1997. str. 21 i dalje.

36 Kelsen, H., Čista teorija prava, Naklada Breza, Zagreb, 2012., str. 13.

37 O utjecaju Kantova tumačenja dualizma činjenica i vrijednosti, bitka i trebanja na pravnu znanost vidi više u: Fikentscher, W., Methoden des Rechts, J. C. B. Mohr (Paul Siebeck), Tübingen, 1976., str. 25 i dalje. 
Kelsenu je poslužio da pokaže iskustvenu neovisnost, odnosno autonomnu egzistenciju pravne norme u odnosu na činjenice. Tako on tumačenje norme temelji na istaknutom dualizmu te za njega norma ima samo idealnu, specifičnu egzistenciju u valjanosti, bez obzira na to postoji li ili ne u stvarnosti nešto što je tom normom trebano, za razliku od stvarnosti neke činjenice, npr. da je određena boja stvarno svojstvo nekog predmeta. ${ }^{38}$ Također, vrijedi spomenuti da na tragu čiste teorije prava Luhmann ističe normu kao temeljni pojam, koja, samim time što propisuje što treba, čini nužnim glavno razlikovanje normi i činjenica. Iz tog razloga, tumači dalje, čista teorija prava prikazuje se kao refleksivna teorija sistema prava za koju tvrdi, u razlici spram Kelsena, da je "prisiljena na apstrakciju i potragu za interdisciplinarnim kontaktima ${ }^{39}$, sa starom osnovnom tezom da se norme ne mogu "izvoditi" iz činjenica te se ne mogu ni opisivati kao činjenice, želi li se poštivati njihova vlastita vrijednost, njihova trebanost, njihov karakter zahtjeva". ${ }^{40}$

Stoga, pitanje koje se može ispravno razumjeti samo u kontekstu razumijevanja dihotomije odnosa činjenica i vrijednosti jest - postoji li odnosno može li postojati zatvoreni normativni sistem prava s obzirom na to da je pravna norma odnosno pravno pravilo uvijek posljedica tumačenja koja normativno vrednuje u odnosu na stvarno, a stvarno u odnosu na normativno. To pitanje nužno se odražava i na tumačenje načela te otvara, među ostalim, još jednu važnu dvojbu: postoji li određen ili odrediv broj pravno obvezujućih načela?

\section{KRITERIJ(I) PRAVNOSTI PRAVNIH NAČELA}

\section{Općenito}

Očito je da različite pravne škole pružaju različite odgovore na pitanja što su to načela, koja su načela pravna i pravno obvezujuća, na temelju kojih kriterija se određuju, a onda i primjenjuju. Drugim riječima, to znači da traženje tih kriterija, što je nužno ako se nastoji sistematizirati novo područje, ovisi o prihvaćanju prethodno opisanih tumačenja pravnog sistema kao ukupnosti pravnih normi ili kao sistema čiji su konstitutivni dijelovi i pravni odnosi i/ili pravne vrijednosti.

Naime, istaknuto je kako postoje načela koja su izričit sadržaj pravne norme te načela koja proizlaze iz određenih (pravnih) tumačenja. Ova prva, sadržana u normi Ustava i/ili zakona, na vrhu su hijerarhijske sistematizacije normi, bez

\footnotetext{
38 Vidi Kelsen, op. cit. u bilj. 14, str. $73-75$.

39 Istaknula autorica.

40 Vidi Luhmann, op. cit. u bilj. 18, str. 12.
} 
obzira na to štiti li se njima vrijednosti koje su isključivo pravne ili ne. Neslaganje u različitim pravnim tumačenjima izaziva druga "vrsta" načela. To neslaganje pokazuju obje dihotomije pravnog sistema, a ono se ponajprije očituje oko njihova (hijerarhijskog) statusa koji je prije svega uvjetovan stupnjem njihove obvezatnosti, ali i (ne)mogućnosti njihove sadržajne i brojčane odredivosti.

\section{Kriterij hijerarhije i obvezatnost pravnih načela}

U određivanju kriterija obvezatnosti pravnih načela istaknula bih jedno od pitanja afirmirano u teoriji, a to je pitanje razlikovanja pravnih pravila i pravnih načela, razlikovanje koje je također obilježeno različitim tumačenjima, čiju okosnicu čini upravo dvojba o tome jesu li načela koja nisu izričit sadržaj norme uopće pravna načela ili neki izvan pravni standardi. Najutjecajnije odgovore pružila je čista teorija prava. Kao dijelove pravnog sistema Kelsen uz pravnu normu navodi i pravna načela shvaćena kao "principi morala, politike i običaja". Ti principi mogu se nazvati "pravnima" samo ako imaju utjecaja na proizvođenje pravnih normi od strane nadležnih autoriteta (npr. putem ujednačene prakse sudova). Međutim, i u tim slučajevima, tumači Kelsen, te norme (u ovom slučaju pojedinačne) valjanost stječu na temelju formalnog pozitivnopravnog načela pravomoćnosti, a ne na temelju principa morala, politike ili običaja. ${ }^{41}$ Naime, kada sud u jednakim slučajevima odlučuje na jednak način, principi morala, politike i običaja kojima odgovara sadržaj neke opće pravne norme ostaje normom različitom od te opće pravne norme. Stoga činjenica da ti principi utječu na proizvođenje pravnih normi za Kelsena ne znači da se oni "pozitiviziraju”, odnosno da postaju sastavni dijelovi pozitivnog prava. Ti principi su samo motivi “- uz druge čimbenike - zakonodavca, suca ili upravnog tijela; i ti motivi - po pozitivnom pravu - nisu pravno obvezujući" te zato nemaju karakter pravne norme. ${ }^{42}$ Vrijedi uočiti kako je i u takvom tumačenju pretpostavljena dihotomija činjenica i vrijednosti: za Kelsena pravna znanost je znanost o normama, što znači da njezin predmet može biti samo formalna struktura pravnih normi, a ne njihov sadržaj u smislu iskustvenih činjenica. Stoga ako se pojam pravno pravilo jasno ne razlikuje od pojma pravnog načela, briše se granica između pozitivnog prava s jedne strane te morala, politike i običaja s druge. Drugim riječima, Kelsen smatra kako se time gubi mogućnost spoznaje i objektivnog opisivanja pozitivnog prava u ime moralno-političkog opravdavanja prava. ${ }^{43}$

$41 \quad$ Vidi Kelsen, op. cit. u bilj. 14, str. 131 - 132.

42 Kelsen, op. cit. u bilj. 14, str. 133.

43 Kelsen, op. cit. u bilj. 14, str. 133. 
Iznesene teze utjecale su na daljnja tumačenja prava u kojima su nerijetko dominirale sljedeće dvojbe neposredno povezane s pitanjem kriterija obvezatnosti pravnih načela koja nisu dio opće pravne norme: dvojbe oko upotrebe samog pojma "pravna načela", pitanje postojanja općeprihvaćenih kriterija razlikovanja pravnih pravila i pravnih načela, što je otvorilo i otvara niz pitanja o tome što pravo uopće jest. U pogledu različite upotrebe pojma "pravna načela" ovdje smatram korisnim iznijeti ukratko Dworkinovo tumačenje iz kojeg postaje očita i njegova kritika pozitivizma. On razlikuje pravna pravila od "načela, politike i drugih vrsta standarda". ${ }^{44}$ Iako pojam "načela" obuhvaća "načela, politike i drugih vrsta standarda", odnosno čitav niz standarda koji nisu pravna pravila, što je u skladu s prethodno navedenim tumačenjem bliskom pozitivizmu, Dworkin ipak navodi distinkciju između politike kao vrste standarda koji predstavljaju neki društveni cilj koji se mora ostvariti, od načela kao standarda koji se moraju poštovati kao, primjerice, zahtjev pravednosti ili pravičnosti ili neke druge dimenzije moralnosti. ${ }^{45}$

Oba opisana pristupa upućuju na dodatne nejasnoće koje nemaju samo terminološki smisao. Riječ je o upotrebi pojmova pravno pravilo, pravno načelo, načelo i standardi. Pritom je najjasnije značenje pojma pravno pravilo pod kojim se razumiju opće pravne norme. Za pravna načela može se ustvrditi da su to ona načela koja su izričito propisana općom pravnom normom, ali i općeprihvaćena pravna načela tumačenja (kao npr. lex specialis). Za ova prva također se može ustvrditi da su hijerarhijski najviše ili temeljne norme ${ }^{46}$, što im onda, samim time, pridaje obilježje obvezatnosti, dok se za ova druga ipak ne može zaključiti da ih obilježje obvezatnosti neuvjetovano dovodi hijerarhijski na najviše mjesto.

Dakle, ono što povezuje pravno pravilo i izričito pravno načelo je obilježje obvezatnosti. Međutim, postoje i znatne razlike. Temeljni problem jest što nema jednoznačnog određenja kriterija razlike između pravnih pravila i pravnih načela te se ona nerijetko uzimaju kao pitanje konvencije. ${ }^{47}$ Pritom postoji prilično slaganje među teoretičarima o tome da je pojam pravnih načela puno složeniji pojam. Tu složenost ovdje ću okarakterizirati s dvama obilježjima koja ima pravna norma koja se smatra i pravnim načelom, obilježja koja navodi Guastini, ali i drugi autori: već istaknuti temeljni karakter te obilježje neodređenosti. ${ }^{48}$ Neodređenost ističe i Dworkin u smislu da kod pravnih pravila vrijedi "sve ili

\footnotetext{
44 Vidi Dworkin, op. cit. u bilj. 12, str. 33 - 34

45 Vidi Dworkin, op. cit. u bilj. 12, str. 33 - 34 .

46 Vidi Guastini, op. cit. u bilj. 13, str. 77 i dalje.

47 Pavčnik, op. cit. u bilj. 25, str. 122.

48 Vidi Guastini, op. cit. u bilj. 13, str. 77 i dalje.
} 
ništa”, dok i ona načela koja najviše nalikuju pravnim pravilima ne izazivaju automatski pravne posljedice. Osim toga, načela imaju dimenziju težine ili važnosti koja pravna pravila nemaju. Ta dimenzija osobito dolazi do izražaja kada su dva načela ili više njih u sukobu te se mora prosuditi koje je načelo važnije. ${ }^{49}$ Slično i Pavčnik tumači kako pravno pravilo izražava vrstu ponašanja, dok pravna načela posreduju “samo" kriterij vrijednosti, usmjeravajući sadržajno opredjeljenje pravnih pravila, njihovo razumijevanje i provedbu. To znači da su pravna načela kao temeljne pravne norme polazna točka primijenjena i određena pravnim normama, odnosno pravna pravila i pravni propisi su konačan proizvod koji pretpostavlja da su ga pravna načela smisleno suoblikovala. ${ }^{50}$ Drugim riječima, obvezna pravna načela predmet su tumačenja i normativne konkretizacije (npr. nullum crimen sine lege certa u kaznenom pravu). Njihova upotrebljivost je veća ako su propisani zakonom te ako su naišli na aktivan odgovor u pravnoj teoriji i praksi, odnosno ako su primijenjeni, a ta primjenjivost ima pouzdanu osnovu u pravnim pravilima, ustanovama i njihovim međusobnim vezama. ${ }^{51}$

\section{Kriterij hijerarhije i otvorenost pravnih načela}

Međutim, normativna konkretizacija ne znači da su pravna načela konkretizirana samo propisom.

Upravo obilježja temeljnosti i neodređenosti pravnih načela imaju važnu ulogu u pravnoj praksi i kod tumačenja prava. Primjerice, na temelju uvida kako pravna načela konkretiziraju i pravosudna tijela, Pavčnik kritizira pravni pozitivizam koji to zanemaruje s obzirom na njihova stajališta da su pravna pravila bitno zatvorena i zaključana. ${ }^{52}$ Naime, očito je problem u tome što se pravna načela ne stvaraju samo zakonodavnim putem nego i pravnim tumačenjem, kao i to da postoje načela koja su plod znanstvene sistematizacije. Stoga pitanje obvezatnosti ustvari podrazumijeva pitanje koliko je institucionalne podrške potrebno da bi se određeno načelo smatralo pravnim pravilom, ali i određeno načelo pravnim načelom.

Također, na temelju navedenog može se zauzeti stav da sva pravna načela nisu obvezujuća na isti način jer je u teškim slučajevima sudac prisiljen više ih tumačiti nego neposredno primjenjivati, za razliku od pravnih pravila, kao i to da sudac nerijetko poseže za izvanpravnim načelima. Riječ je o razumijevanju

\footnotetext{
49 Vidi Dworkin, op. cit. u bilj. 12, str. 36 - 38.

50 Pavčnik, op. cit. u bilj. 25, str. 122.

51 Pavčnik, op. cit. u bilj. 25, str. 122 - 124.

52 Vidi Pavčnik, M., Teorija prava, Cankarjeva založba, Ljubljana, 2001., str. 501.
} 
"doktrine diskrecije" sudaca, koju Dworkin dovodi u pitanje, shvaćene na način da ih suci mogu primjenjivati u nedostatku pravnih pravila, što ujedno znači da nisu za njih obvezujuća, nego ih mogu uzeti u obzir kao izvanpravne standarde odnosno kao autoritete morala, sudskog zanata i sl. ${ }^{53}$ Pritom polemizira s Hartovim razlikovanjem prihvaćanja i valjanosti, razlikovanje koje uvjetuje hoće li određeno načelo biti pravno obvezujuće. Prema Hartu, većina je pravila valjana jer ih je donijela neka nadležna institucija (zakonodavac u obliku zakonskih propisa, suci kao presedane za budućnost). Dworkin to naziva "institucionalnom podrškom” te ističe problem da se ne može utvrditi kriterij koliko i koje je vrste institucionalne podrške potrebno da bi neko načelo postalo pravno načelo te da bi se odredila njegova (hijerarhijska) težina jer se to dokazuje na temelju niza promjenjivih standarda. Ako se pojedino pravno načelo dokazuje navođenjem sudskih i zakonodavnih akata, dakle u praksi dokazanom tehnikom koju podržavaju druga opća pravna načela, to govori, navodi Dworkin, o prihvaćenosti, ali i valjanosti načela. ${ }^{54}$

U temelju ovakvog tumačenja nalazi se teza koju osim Dworkina očito zastupaju i drugi autori, teza da ne postoje opće prihvaćeni temeljni kriteriji razlikovanja pravnih standarda od onih koji to nisu. Stoga kada kritizira pozitivizam, on ustvari kritizira teze o tome što pravo jest, a što nije kao o jasnoj činjenici o kojoj nije moguće teorijsko neslaganje: pravo je ono što su pravne institucije, poput zakonodavca i sudova, odlučile da ono jest. ${ }^{55}$ Drugim riječima, on kritizira tezu o jedinstvenom temeljnom kriteriju pravnosti jer se time previđa važna uloga standarda koja nisu pravila. Za razliku od toga, za Dworkina je pravo odredivo tumačenjem a ne neupitnim činjenicama, pa su i teorijska neslaganja koja postoje posljedica neslaganja oko ispravnih kriterija pravnosti. S obzirom na očito suprotstavljanje bilo kakvom tumačenju da je pravo fiksni skup standarda bilo koje vrste, smatra kako nije moguće fiksno odrediti, odnosno nabrojiti sva načela koja su na snazi jer su mnogobrojna, sporna i njihova težina je važna. ${ }^{56}$

Dakle, temeljni prigovor sadržan je u tezi da se pravni sistem sastoji od pravnih pravila, od (pravnih) načela i standarda čija su bitna (i zajednička!) obilježja suštinska i kvantitativna otvorenost. ${ }^{57}$ Prvo obilježje proizlazi iz svega

53 Vidi Dworkin, op. cit. u bilj. 12, str. 41, $46-47$.

54 Vidi Dworkin, op. cit. u bilj. 12, str. 52 - 53.

55 Vidi Dworkin, op. cit. u bilj. 12, str. 33.

56 Dworkin, op. cit. u bilj. 12, str. 56, 90 i dalje. Na ovakvo tumačenje izričito se poziva i Pavčnik, navodeći da kada bi i pokušali pobrojiti sva važeća prava načela, ne bismo uspjeli zbog brzih promjena i teškoća pri pokušaju njihova hijerarhiziranja po važnosti. Vidi Pavčnik, op. cit. u bilj. 52, str. 501.

57 Vidi Pavčnik, op. cit. u bilj. 52, str. 501. 
onoga što je do sada rečeno o pravnim načelima, posebice o njihovu obilježju neodređenosti, a očituje se i u tome što ona predstavljaju neuhvatljivi vrijednosni kriterij koji usmjerava sadržaj i način izvršavanja pravne norme. Otvorenost se također odnosi i na broj pravnih načela, čime se pokazuje dodatni vid obilježja neodređenosti, kako onih izričitih, tako i onih pravnih načela koja posredno proizlaze iz pravne norme.

\section{Podjela pravnih načela}

Pravna načela su ta koja omogućuju logičnu i vrijednosnu povezanost, pa u tom smislu i zatvorenost pravnog sistema. Međutim, s obzirom na to da je pravni sistem obilježen i otvorenošću, to bi nužno značilo, na temelju prethodnih pojašnjenja, da broj pravnih načela nije neki fiksni skup pravnih normi. U kontekstu teorijskih pristupa tu otvorenost odnosno neodredivost poentirala sam razlikovanjem pravnih pravila, pravnih načela, načela i standarda, što, vjerujem, predstavlja korektan temelj za daljnja istraživanja. Štoviše, određivanje kriterija za njihovo razlikovanje, posebice za razlikovanje pravnih pravila i pravnih načela, osobito je važno kada načela nisu izričito formulirana pravnom normom. U području visokog obrazovanja i znanosti, osim u temeljnom zakonu, ZZDVO-u, načela su izričito propisana u ZSZDSO-u, ZHKO-u te Kolektivnom ugovoru za znanost i visoko obrazovanje. ${ }^{58}$

Iako kao polazište određivanja pravnih načela koristim normativistički pristup, držim da istaknute dihotomije pravnog sistema prikazane u kontekstu pojedinih teorijskih pristupa opravdavaju ranije iznesenu tezu kako bi za sveobuhvatnije određivanje pravnih načela u dijelu koji još nije sistematiziran bilo primjerenije koristiti “integrativni” metodološki pristup, koji ipak ne bi trebao biti određen samo empirijski, a pogotovo ne bi trebao biti sveden na pozitivističku metodu. ${ }^{59}$ Naime, svi opisani prijepori imanentni su empirijskom pristupu

58 Zanimljiva novina i iznimka u odnosu na prijašnji kolektivni ugovor jer se sada u čl. 2. naslovljenom "Pravna načela" navode pojedina načela radnog prava. Vidi Kolektivni ugovor za znanost i visoko obrazovanje, Narodne novine, br. 9/2019.

Jedno od obilježja pravnog pozitivizma, koje ističe Radbruch, jest to da se primarno ne istražuju pravne vrijednosti nego samo empirijsko istraživanje prava. Stoga mjesto filozofije prava zauzima opća teorija prava, istražujući pravne pojmove (pravni subjekt, pravni objekt, protupravnost i sl.) zajedničke većem broju pravnih područja, grana te ih uspoređuje s različitim pravnim porecima. Takvim pristupom dolazi se do pojmova koji ne pripadaju jednoj empirijskoj općoj teoriji prava nego samo jednoj teoriji pozitivnog prava. Budući da su ti pojmovi dobiveni na temelju kritičke analize pozitivnog prava, oni nikada neće dovesti do jednog vrednovanja pozitivnog prava. 
tumačenju načela: iz pozitivnopravnih tekstova, različitih izvan pravnih ciljeva i vrijednosti. Stoga problem sistematiziranja pravnih načela, koji je posljedica empirijskog tumačenja, jasno pokazuje i problem (ne)mogućnosti njihova poopćavanja, odnosno prostorne i vremenske neuvjetovanosti, koji ipak zahtijeva i svoje teorijsko objašnjenje. Na to je već upozorio Kant.

Prilikom sistematiziranja pravnih načela "sveučilišnog prava i prava znanstvenih organizacija" osim spomenutih pojmovnih razlikovanja uzimam u obzir i podjelu načela prema Guastiniju. On razlikuje: ustavna i zakonska načela, "opća načela u užem smislu" (načela koja vrijede za čitav pravni sistem) i "posebna načela” (načela koja obilježavaju pojedino područje) te „izražena“ $i$ „neizražena“ načela. „Izražena“ su ona izrijekom formulirana pravnom normom te ona koja se mogu izvesti putem tumačenja. „Neizražena“ su ona koja nisu izrijekom formulirana pravnom normom, nego su ih "konstruirali" tumači, pretpostavljajući da je to načelo sadržano u diskursu prava. Njih izvode pravnici: ponekad iz manjeg ili većeg skupa pravila, a ponekad iz ukupnosti pravnog poretka ${ }^{60}$

U skladu s tim, najprije ću navesti načela upravnog prava koja vrijede i za "sveučilišno pravo i pravo znanstvenih organizacija". Nadalje, prema izvorima navodit ću načela koja proizlaze iz Ustava, prakse USRH-a, međunarodnih ugovora te zakona. Riječ je o propisima koji uređuju isključivo predmetni dio pravnog sistema. To ujedno znači da ovom sistematizacijom nisu obuhvaćena ne samo opća odnosno općeprihvaćena pravna načela, što i nije tema ovoga rada, nego europski i drugi pravni izvori koji se ne primjenjuju samo na ovo, nego i na druge dijelove pravnog sistema (npr. Zakon o javnoj nabavi i sl.).

\section{NAČELA "SVEUČILIŠNOG PRAVA I PRAVA ZNANSTVENIH ORGANIZACIJA"}

\section{Načela upravnog prava}

Načela na kojima se temelje propisi u visokom obrazovanju i znanosti dobrim dijelom proizlaze iz posebnog pravnog statusa pojedinih visokih učilišta, položaja koji svoje uporište ima u Ustavu, te u činjenici da visoka učilišta, kao i sve znanstvene organizacije, obavljaju javnu službu u formalnom i materijalnom

Drugim riječima, takav pristup ne može pružiti odgovore o ispravnom pravu, nego samo odgovore na pitanje kako se određeno pravo može ispravno shvatiti. Radbruch, G., Filozofija prava, Naklada Breza, Zagreb, 2019., str. 42 - 43.

60 Vidi Guastini, op. cit. u bilj. 13, str. $81-84$. 
značenju ${ }^{61}$ Poseban pravni položaj visokih učilišta proizlazi iz ustavnog jamstva autonomije na temelju kojeg, pak, proizlazi već istaknuto razlikovanje posebno relevantno i za određivanje načela, a to je razlikovanje sveučilišta i sveučilišnih visokih učilišta od ostalih visokih učilišta i znanstvenih organizacija. Osim toga, njegova primjena očituje i razlikovne dijelove u primjeni ostalih načela koja vrijede u upravnom pravu, a odnose se na ustanove koje imaju javne ovlasti. S obzirom na to da se na djelovanje visokih učilišta kao i na djelovanje znanstvenih organizacija supsidijarno primjenjuje Zakon o ustanovama ${ }^{62}$, najprije ću navesti načela koja se u teoriji navode kao imanentna ustanovama ${ }^{63}$ :

načelo samostalnosti

načelo kontinuiteta

načelo dužnosti pružanja usluga iz kruga djelatnosti

načelo nemerkantilnosti ${ }^{64}$

načelo jednakosti uživalaca službe

načelo javnosti. ${ }^{65}$

Načela koja obilježavaju ustanove vrijede i za javne službe. Međutim, javnu službu određuju još dva elementa: djelatnost koja je prema svojoj prirodi takva da je prijeko potrebna za ostvarivanje općih interesa te pravna norma koja takvu djelatnost izdvaja kao posebnu javnu službu dajući joj poseban pravni status. ${ }^{66}$ $\mathrm{Na}$ temelju toga proizlazi još jedno načelo koje vrijedi za visoka učilišta i za sve znanstvene organizacije - načelo primata javne službe u odnosu na privatnu službu - što podrazumijeva i njihov diferencijalni režim. Iako ono vrijedi i danas u području visokog obrazovanja i znanosti, napravljene su bitne promjene u odnosu na Zakon o visokim učilištima. ${ }^{67}$ Kao što ću dalje pokazati, pojedina navedena

${ }_{61}$ Za formalni pojam javne službe bitno je da službu obavlja neka javnopravna osoba, a za materijalno značenje tog pojma bitno je da je služba od posebnog interesa za društveno okruženje te time u pravilu dobiva posebni pravni režim. Vidi Borković, I., Upravno pravo, Informator, Zagreb, 1995., str. 15.

62 Vidi čl. 5. st. 1. i čl. 48. st. 1. ZZDVO-a, koji glasi: Sveučilišta, veleučilišta i visoke škole osnivaju se kao ustanove.

63 Više o sistematizaciji upravnog prava vidi u: Ivančević, V., Institucije upravnog prava, Pravni fakultet Zagreb, Zagreb, 1983.

64 Vidi čl. 107. st. 2. ZZDVO-a.

65 Vidi čl. 53. st. 1. ZZDVO-a.

66 Borković, op. cit. u bilj. 61, str. 15. Vidi čl. 47. st. 2. ZZDVO-a.

67 Narodne novine, br. 59/1996, 02/1999, 14/2000 i 26/2000, 67/2000, 94/2000 i 129/2000 (dalje u tekstu: ZVU). ZVU-om bila je predviđena mogućnost osnivanja privatnih učilišta, ali više kao iznimka. ZZDVO puno izričitije otvara mogućnost 
načela normativni izraz imaju u Ustavu ili/i u zakonima koji uređuju područje visokog obrazovanja i znanosti.

\section{Ustavna načela "sveučilišnog prava i prava znanstvenih organizacija"}

\subsection{Pravna načela koja proizlaze iz Ustava}

Načela i jamstva ${ }^{68}$ koja neposredno uređuju područje visokog obrazovanja i znanosti:

načelo dostupnosti srednjoškolskog i visokoškolskog obrazovanja pod jednakim uvjetima (čl. 66. st. 1. Ustava)

jamstvo autonomije sveučilišta (čl. 68. st. 1. Ustava)

načelo samostalnog ustroja i djelovanja sveučilišta (čl. 68. st. 2. Ustava)

jamstvo slobode znanstvenog, kulturnog i umjetničkog stvaralaštva (čl. 69. st. 1. Ustava)

načelo zaštite znanstvenih, kulturnih i umjetničkih dobra kao duhovnih narodnih vrednota (čl. 69. st. 3. Ustava) ${ }^{69}$

jamstvo zaštite moralnih i materijalnih prava stečenih stvaralaštvom (čl. 69. st. 4. Ustava).

\subsection{Pravna načela koja proizlaze iz prakse Ustavnog suda $R H$}

Prihvaćajući prethodno tumačenje da su neizričita pravna načela ona koja su "konstruirali" tumači, podjela neizričitih načela koja u ovom dijelu slijedi

osnivanja privatnih visokih učilišta. Ipak, iz ZZDVO-a i drugih zakona proizlazi diferencijalni režim javnih visokih učilišta u odnosu na privatna, koji se očituje npr. u kriterijima za njihovo osnivanje i postupcima vrednovanja.

${ }^{6}$ O značenju pojmova "vrednota", “jamstvo", "načelo” vidi više u: Odgovori na upitnik za XVII. kongres Konferencije Europskih ustavnih sudova, Nacionalno izvješće, USRH, Zagreb, 2016., str. 2 i dalje. Dostupno na https://www.usud.hr/sites/default/files/ dokumenti/Upitnik_i_tema_XVII._kongresa_Konferencije_europskih_ustavnih_ sudova_odrzanog_u_Batumiju_Gruzija_od_28._lipnja_do_1._srpnja_2017. pdf\#page5 (7. rujna 2019.).

69 Važno je primijetiti da se, osim ovog stavka, u tekstu Ustava samo na još jednom mjestu spominje pojam "vrednote", i to u čl. 3. koji propisuje najviše vrednote ustavnog poretka RH. O značenju čl. 3. Ustava, koji je temelj tumačenja ostalih ustavnih normi, vidi više u: Smerdel, B.; Sokol, S., Ustavno pravo, Sveučilišna tiskara d.o.o., Zagreb, 2006., str. 114 i dalje. 
temelji se na: ujednačenoj praksi USRH-a, ustavnim ovlastima USRH-a, protumačenim normama Ustava ili/i zakona. Riječ je o uvjetima za koje smatram da predstavljaju kriterije institucionalne podrške za određivanje pravnih načela koja ovdje navodim. Pritom su uzete u obzir pojedine odluke donesene i prije ZZDVO-a, u kojima su izražena (načelna) pravna stajališta dosljedno provedena i u kasnijoj ustavnosudskoj praksi. ${ }^{70}$ Osim toga, u navedenim odlukama i/ili rješenjima dodatno su protumačena pojedina jamstva i načela Ustava ${ }^{71}$, pa neka od njih ponovno navodim. Uglavnom, riječ je o sljedećim pravnim načelima:

\section{Jamstvo autonomije i načelo akademske slobode i akademske samouprave}

U gotovo svim odlukama i/ili rješenjima koja su predmet ovog rada USRH je ocijenio neustavnim pojedine odredbe temeljnih zakona, tadašnjeg ZVU-a te ZZDVO-a, ponajviše zbog nepoštovanja ustavnog jamstva autonomije te načela akademske slobode i akademske samouprave. U O,R USRH - I zauzeo je načelno stajalište koje do danas dosljedno i ujednačeno primjenjuje $\mathrm{e}^{72}$ :

70 Riječ je o sljedećim odlukama i/ili rješenjima USRH-a:

Narodne novine, br. 14/2000, 26/2000 - ispr. 67/2000 - O,R USRH br: U-I902/1999 od 26. siječnja 2000. (dalje u tekstu: O,R USRH - 1); Narodne novine, br. 94/2000 - Odluka USRH br: U-I-843/2000 od 13. rujna 2000. (dalje u tekstu: O USRH - 2); Narodne novine, br. 177/2003 - Rješenje USRH br: U-I-1441/2001 od 23. listopada 2003. (dalje u tekstu: R USRH - 3); Narodne novine, br. 2/2007 - Odluka USRH br: U-I-1707/2006 od 20. prosinca 2006. (dalje u tekstu: O USRH - 4); Narodne novine, br. 2/2007 - Odluka USRH br: U-I-4585/2005, U-I-4799/2005, U-I-2446/2006 i U-I-3502/2006 od 20. prosinca 2006. (dalje u tekstu: O USRH 5); Narodne novine, br. 99/2013 - Odluka USRH br: U-II-1304/2013 od 16. srpnja 2013. (dalje u tekstu: O USRH - 6); Narodne novine, br. 101/2014 - O,R USRH br: U-I-5578/2013 i U-I-3633/2014 od 18. srpnja 2014. (dalje u tekstu: O,R USRH - 7); Narodne novine, br. 41/2016 - Odluka USRH br: U-I-351/2016 od 20. travnja 2016. (dalje u tekstu: O USRH - 8); Narodne novine, br. 46/2017 - Odluka USRH br: U-II-6251/2016 od 25. travnja 2017. (dalje u tekstu: O USRH - 9); Rješenje USRH br. U-I-1102/2009 od 21. studenoga 2017. (dalje u tekstu: R USRH - 10); Rješenje USRH br. U-I-3416/2007 od 19. prosinca 2017. (dalje u tekstu: R USRH - 11); Rješenje USRH br. U-I-4613/2015 od 30. siječnja 2018. (dalje u tekstu: R USRH - 12); Rješenje USRH br. U-I-4981/2013 i U-I-1454/2014 od 9. listopada 2018. (dalje u tekstu: R USRH - 13). Rješenja koja nisu objavljena u Narodnim novinama dostupna na https://sljeme.usud.hr/usud/praksaw.nsf/vSignaturaPoGodiniRije.xsp (7. rujna 2019.).

71 Primjerice, načelo dostupnosti srednjoškolskog i visokoškolskog obrazovanja pod jednakim uvjetima USRH protumačeno je u O USRH - 5.

72 Vidi O,R USRH - 1, t. II, str. 7 - 9, III, I - 3; O USRH - 2, t. 6; O USRH - 4, t. 6 i 8; O USRH - 5, t. 8 - 9; O,R USRH - 7, t. 14-15; O USRH - 8, t. 21; R USRH - 11, 
“...Sud je zauzeo načelno stajalište da članak 67. Ustava sadrži:

- ustavno utvrđenje da je autonomija nužna za samo postojanje sveučilišta, jer sveučilište, kao ustanova koja stvara nove znanstvene spoznaje i uvodi studente u znanosti, može postojati samo u mjeri u kojoj samostalno uređuje svoje ustrojstvo i djelovanje. To je sveučilište organizacijski i funkcionalno neovisno o drugim tijelima koja imaju vlast ili drugu moć da utječu na uređenje ustrojstva i na djelovanje sveučilišta ${ }^{73}$;

- ustavno utvrđenje da sveučilište ima pravo samostalno odlučivati o svom ustrojstvu i djelovanju, u skladu sa zakonom, što znači da odlučivanje o ustrojstvu i djelovanju pripada, silom ustavne odredbe, u područje akademske samouprave (domaine reservé) sveučilišta". ${ }^{74}$

U istoj Odluci navodi se kako je za razradu ustavnog jamstva autonomije sveučilišta osobito važna odredba čl. 3. st. 2. tadašnjeg ZVU-a jer "primjerično razrađuje načela akademskih sloboda i akademske samouprave". To su: sloboda znanstvenog, umjetničkog i tehnološkog istraživanja i stvaralaštva, sloboda utvrđivanja obrazovnih, znanstvenih, umjetničkih i stručnih programa, sloboda izbora nastavnika i čelnika, odlučivanja o kriterijima upisa studenata te utvrđivanja unutarnjeg ustroja. Također, nadalje se pojašnjava kako navedene slobode "pretpostavljaju i pravo sveučilišta da o svakome od njih donosi opće i pojedinačne akte, uključujući statut" ${ }^{75}$ Međutim, iz ovakvog tumačenja, razrađenog u ovoj, ali i kasnijim odlukama/rješenjima, proizlaze još neka načela. Prije svega mislim na načelo zabrane zakonskog ograničavanja autonomije sveučilišta te načelo zaštite zatečenog stanja u funkciji ostvarivanja autonomije sveučilišta. Uz pojedina od njih ukratko ću navesti tumačenja USRH-a koja ih opisuju.

\section{Načelo zabrane zakonskog ograničavanja autonomije sveučilišta}

“...temeljni sadržaj autonomije sveučilišta, to jest onaj koji nije dopušteno ograničavati zakonskim odredbama niti je dopušteno da ga ograničavaju osnivatelji, podupiratelji ili pak nositelji stručnog nadzora nad njegovim radom."

t. 8; R USRH - 12, t. 10.

73 Funkcionalnu i organizacijsku neovisnost o drugim tijelima koja imaju vlast ili drugu moć da utječu na ustrojstvo i na djelovanje sveučilišta može se smatrati i tumačenjem načela samostalnog ustroja i djelovanja iz čl. 68. st. 2. Ustava, što je USRH tumačio i u kasnijim odlukama ili/i rješenjima: O USRH - 4, t. 8; O USRH -5 , t. 8.

74 Vidi O,R USRH - 1, t. II, str. 7 i dalje.

75 Vidi O,R USRH - 1, t. III, 3. 
“...zakonska ograničenja autonomije sveučilišta dopustiva samo zbog razloga navedenih u čl. 16. Ustava. Međutim, i u tom slučaju konkretni javni interes da se autonomija sveučilišta ograniči mora biti jači od interesa sveučilišta da se autonomija ostvari..."76

“...temeljni sadržaj akademske samouprave, koji nije dopušteno ograničavati propisivanjem izvornih ili kontrolnih ovlasti države u tim pitanjima, pa bila država i sam osnivatelj, podupiratelj i nadziratelj stručnog rada sveučilišta. Nadalje, pitanja koja se tiču ustrojstva i djelovanja sveučilišta, a koja ne predstavljaju izvorne ovlasti sveučilišta obuhvaćene akademskom samoupravom, moraju biti propisana zakonom i ne mogu biti prenesena na tijela izvršne vlasti države."77

Načelo zaštite zatečenog stanja u funkciji ostvarivanja autonomije sveučilišta

Ovo načelo proizlazi iz O USRH - 2 u kojoj je USRH koristeći se izrazom "načelo obvezatnosti zaštite zatečenog stanja" zauzeo

“...načelno ${ }^{78}$ stajalište da svako stanje koje je na sveučilištu zatečeno, a u funkciji je ostvarivanja autonomije sveučilišta iz čl. 67. st. 1. Ustava i poticanja razvitka znanosti iz čl. 68. st. 2. Ustava - pod uvjetom da nije neracionalno i da nije u sukobu s drugim Ustavom zaštićenim vrijednostima - novim zakonom samo mora biti zaštićeno" ${ }^{79}$

Načelo binarnog sustava visokog obrazovanja

Riječ je o načelu koje proizlazi iz tumačenja jamstva autonomije, odnosno ustavnih i zakonskih razlika sveučilišta i sveučilišnih visokih učilišta od drugih visokih učilišta i znanstvenih organizacija te razlika između sveučilišnih i stručnih studija, koje temelj imaju u Ustavu i u zakonima. ${ }^{80} \mathrm{U}$ skladu s tim, u O USRH - 8 navodi se da je visoko obrazovanje "utemeljeno na binarnom sustavu sveučilišnih i stručnih studija". ${ }^{81}$

76 Vidi O,R USRH - 1, t. II, str. 9.

77 Vidi O,R USRH - 1, t. II, str. 11.

78 Istaknula autorica.

79 Vidi O USRH - 2, t. 6. Ponovljeno u O,R USRH - 7, t. 15 i 18, R USRH - 11, t. 9.

80 Neke od zakonskih normi na temelju kojih proizlaze razlike jesu: čl. 3. st. 1. i 2., čl. 22. st. 1., čl. 69., 70., 83., 92., 99. ZZDVO-a; čl. 20. ZOKZVO-a; čl. 3. - 11. ZASNAS-a.

81 Vidi O USRH - 8, t. 13. 
"Ona [sveučilišta i visoka učilišta u sastavu sveučilišta] se od ostalih visokih učilišta ustavno razlikuju po tome što se samo na njih odnosi ustavno jamstvo slobode znanstvenog stvaralaštva iz čl. 68. st. l. Ustava, što za sobom povlači i njihovu zakonsku razliku, jer samo sveučilišta i visoka učilišta u sastavu sveučilišta izvode studije koji pripremaju i za znanstveni rad". 82

"To je stoga što sveučilišta djeluju kao posebna vrsta znanstvene zajednice, jer je njegova zadaća - za razliku od svih drugih institucionalnih oblika znanstvene zajednice - da razvija cjelinu znanosti, a da se taj razvoj odvija u kritičkoj raspravi sa studentima (napose poslijediplomantima)". ${ }^{83}$

Izričito tumačenje da se jamstvo autonomije ne odnosi na veleučilišta te koji su sve pravni učinci toga sadržano je, među ostalim, u R USRH - 3 USRH-a:

"U odnosu na veleučilište, prema tome, zakonodavac je ovlašten da temeljem čl. 2. st. 4. alineje 1. Ustava slobodno uređuje odnose vezane za njegovo osnivanje, ustrojavanje, tijela, nadležnosti te prava, obveze i odgovornosti, a da istodobno nije vezan ograničenjima koja proizlaze iz ustavnog jamstva autonomije sveučilišta". ${ }^{84}$

\section{Zakonska načela "sveučilišnog prava i prava znanstvenih organizacija"}

\subsection{Pravna načela koja proizlaze iz međunarodnih ugovora}

3.1.1. Konvencija o priznavanju visokoškolskih kvalifikacija u području Europe

Na temelju odjeljka III članaka III.l. - III.5. ZPKPVKPE-a, naslovljenog "Osnovna načela vrednovanja kvalifikacija”, proizlaze sljedeća načela: načelo zabrane diskriminacije u postupku vrednovanja kvalifikacija (čl. III.I.) načelo transparentnosti informacija, kriterija i postupaka vrednovanja kvalifikacija (čl. III.2 - III.4; čl. 13., 14., 85. ZZDVO-a) načelo postupanja u razumnom roku (čl. III.5.).

82 Vidi O,R USRH - 1, t. III. 3.1. Ponovljeno O USRH - 8, t. 20.

83 Vidi O USRH - 2, t. 6.

84 Vidi R USRH - 3, t. 7. Ponovljeno u O USRH - 4, t. 8, O USRH - 8, t. 21, R USRH -13 , t. 17.3. 


\subsection{Pravna načela koja proizlaze iz zakona}

\subsubsection{Zakon o znanstvenoj djelatnosti i visokom obrazovanju}

U čl. 2. ZZDVO-a propisana su "Osnovna načela u znanosti i visokom obrazovanju". Stavkom 2. propisana su načela koja vrijede za znanstvenu djelatnost, a stavkom 3. ona koja vrijede samo za visoko obrazovanje. Riječ je o sljedećim načelima:

načelo slobode i autonomije stvaralaštva

načelo akademskih sloboda, akademske uprave i autonomije sveučilišta

načelo otvorenosti i javnosti rada (čl. 53. st. 1. ZZDVO-a)

načelo etičnosti znanstvenika (čl. 20. st. 1. i 112. ZZDVO-a)

načelo povezivanja sa sustavom obrazovanja (čl. 66. st. 1. ZZDVO-a)

načelo primjene međunarodnih mjerila kvalitete i usklađivanja sa europskim sustavom visokog obrazovanja (čl. 69. st. 4. - 6., čl. 70. st. 4., čl. 76. st. 4., čl. 78. st. 2. ZZDVO-a)

načelo zaštite specifičnosti nacionalnih sadržaja (čl. 78. st. 2. ZZDVO-a)

načelo zaštite intelektualnog vlasništva

načelo nedjeljivosti sveučilišnog nastavnog, znanstvenog i umjetničkog rada (čl. 66. st. 1. ZZDVO-a)

načelo partnerstva akademske zajednice (čl. 66. st. 1., čl. 76. i 103. ZZDVO-a)

načelo zaštite ljudskih prava (čl. 20. st. 1. ZZDVO-a)

načelo jedinstva stručnog i obrazovnog rada u svrhu osposobljavanja za specifična stručna znanja i vještine

načelo razvoja koncepta cjeloživotnog obrazovanja

načelo povezivanja s društvenom zajednicom i razvoja odgovornosti članova akademske zajednice (čl. 4. st. 6., čl. 66. ZZDVO-a).

Jamstvo autonomije detaljnije je razrađeno čl. 4. ZZDVO-a. U odnosu na prijašnji čl. 3. ZVU-a važeće norme dopunjene su novim načelom opisanim u st. 5.: "autonomija sveučilišta na svim sveučilišnim visokim učilištima”. To načelo obuhvaća: uređenje unutarnjeg ustroja i utvrđivanje programa, financijsku autonomiju, autonomiju u razvoju međunarodne suradnje i projektima te ostale oblike autonomije predviđene ZZDVO. U odnosu na prijašnje norme novina je i što akademska samouprava visokih učilišta obuhvaća upravljanje resursima s kojima raspolažu visoka učilišta. Iako nigdje nije detaljnije pojašnjeno značenje pojma "resursi", niti se u ZZDVO-u i u drugim zakonima taj pojam zapaženije koristi ${ }^{85}$, primjena tog na-

85 U Zakonu o Hrvatskom kvalifikacijskom okviru koristi se pojam "potencijali”. 
čela u kontekstu drugih "reformskih" zakona radi uvođenja sustava osiguravanja kvalitete te kvalifikacijskog sustava kao njegove dopune upućuju na određena europska načela i standarde koja su, kao što ću uskoro pokazati, tim zakonima dobili nerazrađenu normativnu podršku, dakle ne i normativnu konkretizaciju.

\subsubsection{Zakon o studentskom zboru i drugim studentskim organizacijama}

Na temelju čl. 2. ZSZDSO-a "Načela studentskih organizacija" proizlaze sljedeća načela:

načelo slobode studentskog udruživanja $i$ djelovanja u studentskim udrugama $i$ studentskim organizacijama (čl. 2. st. 2. ZSZDSO-a)

načelo zabrane diskriminacije studenata s obzirom na članstvo $i$ rad $u$ studentskim organizacijama (čl. 2. st. 4. ZSZDSO-a).

\subsubsection{Zakon o Hrvatskom kvalifikacijskom okviru}

Čl. 3. ZHKO-a nosi naziv "Načela i ciljevi HKO" pa je samo na temelju toga članka teško razabrati koja bi to bila pravna načela - a koji vanjski ciljevi - na kojima bi se trebao temeljiti budući kvalifikacijski sustav. Međutim, s obzirom na to da je riječ o "reformskom" zakonu, u čl. 2. su, kao i kod drugih zakona koji imaju sličnu funkciju (npr. čl. 1. ZPKPVKPE-a, čl. 2. ZPIOK-a, čl. 2. ZOKZVO-a) pravno određeni temeljni pojmovi. Ti pojmovi samo jednim dijelom mogu poslužiti kao uporište za određivanje neizričitih pravnih načela. ${ }^{86}$ Njihovo zakonsko određivanje više je posljedica stvaranja novih društvenih odnosno pravno relevantnih odnosa. Ipak, povezujući čl. 2. i 3. ZHKO-a, ali i navedene članke s ostalim zakonima, mogu se odrediti pojedina neizričita načela, koja ću navesti skupno u sljedećem odjeljku, zajedno s oznakama normi svih zakona na temelju kojih one proizlaze.

\subsection{Neizričita načela koja proizlaze iz zakona}

Prilikom određivanja neizričitih zakonskih načela uzela sam u obzir sve zakone, s posebnom pažnjom usmjerenom na spomenute pravne odredbe

86 Pavčnik u tumačenju hijerarhijske superiornosti zakonskog jezika ističe pravne odredbe pojmova jer njima zakonodavac podrazumijeva pojmove koje smatra pravno važnima, pa samim time služe i kao uporište za određivanje temeljnih (načelnih) normi. Vidi Pavčnik, op. cit. u bilj. 52, str. 378. 
pojmova. Pritom sam uporište pronašla u čl. 53. temeljnog zakona. Riječ je o članku koji opisuje zadaće sveučilišta, ali i drugih znanstvenih organizacija, te temeljna obilježja funkcionalne integracije čije je ostvarivanje dobrim dijelom uvjetovano procesom europeizacije. Osim činjenice ulaska u Europsku uniju pod procesom europeizacije mislim i na činjenicu da je donošenju ZZDVO-a prethodilo potpisivanje niza europskih deklaracija kojima se Republika Hrvatska obvezala na normativno usklađivanje s novim, uglavnom političkim ciljevima u procesu stvaranja Europskog prostora visokog obrazovanja, razvijajući pritom i neka nova načela. Riječ je o deklaracijama koje nemaju status međunarodnih ugovora, već predstavljaju popis standarda koje bi države potpisnice trebale ostvariti. Pojedini standardi postali su pravnom normom zakona, ali bez jasne i provedbeno neizvjesne konkretizacije. ${ }^{87}$

Na temelju navedenog, navodim sljedeća načela:

načelo primjene međunarodnih mjerila kvalitete i usklađivanja s europskim sustavom visokog obrazovanja (čl. 69. st. 4. - 6., čl. 70. st. 4., čl. 76. st. 4., čl. 78. st. 2. ZZDVO-a, čl. 2., 4. st. 1. ZOKZVO-a, čl. 2., 11. ZHKO-a. Načelo je navedeno i u čl. 2. ZZDVO-a)

načelo europskog integriranja sustava visokog obrazovanja (čl. 69. ZZDVO-a, čl. 18. ZOKZVO-a, čl. 2. i 3. ZHKO-a)

načelo zabrane diskriminacije (čl. 3. i 2. ZHKO-a. Načelo je navedeno i u čl. III.l. ZPKPVKPE-a)

načelo partnerstva dionika i nositelja kvalifikacijskog sustava (čl. 2. i 3. ZHKO-a) načelo cjeloživotnog učenja (čl. 76.a ZZDVO-a, čl. 2. i 3. ZHKO-a. Načelo je navedeno i u čl. 2. ZZDVO-a)

načelo poticanja mobilnosti (čl. 75., 76. ZZDVO-a, čl. 13. ZOKZVO-a, čl. 2. i 3. ZHKO-a)

načela poticanja konkurentnosti te uspostave jasnih i prepoznatljivih ishoda učenja $i$ kvalifikacija (čl. 30. st. 1., čl. 54. st. 6., čl. 66., čl. 76., čl. 78. st. 3. ZZDVO-a, čl. 3. ZASNAS-a, čl. 1. st. 2., čl. 3. ZHKO-a).

87 Primjerice, na temelju dokumenta "Europski standardi i smjernice za osiguravanje kvalitete $\mathrm{u}$ visokom obrazovanju" provode se postupci vrednovanja, dokumenta koji je spomenut u čl. 76. st. 4. ZZDVO-a, čl. 4. st. 1. ZOKZVO-a. Također, za pravno određenje pojedinih pojmova koji predstavljaju temelj stvaranja budućih pravnorelevantnih odnosa u sustavu kvalitete i kvalifikacija upotrebljavaju se izrazi uvjetovani procesom nastajanja, dakle bez stalnih i preciznih obilježja, kao primjerice EQF, QF-EHEA, vidi čl. 2. i 11. ZHKO-a. Više o drugim europskim dokumentima i strategijama te njihovu utjecaju na propise vidi u: Grubišić, K., Normativne pretpostavke društva znanja, u: Afrić, V. et al. (ur.), Društvene pretpostavke društva znanja, FF press, Zagreb, 2011., str. 109 i dalje. 


\section{ZAKLJUČAK}

Uvodno sam naznačila kako je istraživanje pravnih načela "sveučilišnog prava i prava znanstvenih organizacija" nužna pretpostavka potpunije sistematizacije ovog dijela pravnog sistema. Međutim, postoje još dva "vanjska" razloga koji opravdavaju tu potrebu. Prvi je učestala izmjena zakona, ali i drugih propisa koji uređuju ovo područje. ZZDVO je od stupanja na snagu 2003., dakle u 16 godina, imao 12 izmjena. S tim je povezan i drugi razlog. USRH je u razdoblju od 2000. godine (što je opravdano uzeti kao razdoblje trajanja reforme s obzirom na to da je Bolonjska deklaracija potpisana 1999.) do danas u zakonima i drugim propisima koji uređuju područje visokog obrazovanja i znanosti šest puta utvrdio nepoštovanje jamstva autonomije sveučilišta, ali i niza općih pravnih načela i temeljnih ustavnih vrednota koji nisu bili obuhvaćeni ovim radom (npr. načelo vladavine prava, načelo razmjernosti, načelo pravne sigurnosti, pravne izvjesnosti, poštovanja zabrane retroaktivnog djelovanja zakona, načelo jednakosti odnosno zabrane materijalne diskriminacije po osnovi naobrazbe).

Iako su pravna načela ta koja određuju temeljne vrijednosti, pa samim time i obvezuju na primjenu, njihova primjena nije neuvjetovana. To ponajbolje pokazuju, među ostalim, tumačenja o ustavnom jamstvu autonomije i načelu akademskih sloboda i akademske samouprave kao sigurno hijerarhijski najvišem načelu "sveučilišnog prava i prava znanstvenih organizacija” i ishodišnom vodiču za tumačenja ostalih načela. Iako samo u iznimnim i opravdanim slučajevima, ako se ostvare pretpostavke čl. 16. Ustava, primjena tih načela ipak je uvjetovana načelom razmjernosti (temeljnih sloboda u odnosu na akademsku slobodu). Stoga, iako je u ovom radu hijerarhija pravnih načela određena prema izvorima, navedeni primjer pokazuje kako je i ta hijerarhija uvjetovana mjerom važnosti pojedinih temeljnih ustavnih vrednota i jamstva u slučajevima kada dolazi do njihova sukoba.

Nemogućnost neuvjetovane primjene pravnih načela posljedica je obiju istaknutih dihotomija pravnog sistema, uočljivih kroz obilježje temeljnosti, ali ponajviše kroz obilježje neodređenosti odnosno otvorenosti pravnih načela. Naime, uza sve navedene razlike između pravnih pravila i pravnih načela koje potvrđuju i prethodnu tvrdnju, postoji još jedna koja dodatno naglašava dihotomiju odnosa činjenica i vrijednosti. Dok pravna pravila obuhvaćaju zatvoreno činjenično stanje u smislu da će se određeno pravilo primijeniti ako se ostvare činjenice, načela i u tom smislu karakterizira (veća) činjenična otvorenost.

I konačno, s obzirom na istaknuta neslaganja oko pravnog statusa u smislu obvezatnosti pojedinih načela ili/i standarda koji odražavaju neke šire društvene vrijednosti, činjenica je da su u ovom dijelu pravnog sistema u mnogim zakonima, doduše s istim stupnjem neodređenosti, ti standardi dobili svoj normativni, 
iako samo - deklaratorni - izraz. S obzirom na to da te norme izazivaju pravne posljedice, pitanja o načinu primjene tih načela i standarda, u smislu primjenjuju li se samo supsidijarno te je li njihova primjena u skladu s europskim pravnim izvorima, svakako su neka od onih koja će obilježiti daljnja istraživanja. Ona će, vjerujem, doprinijeti, zajedno s istraživanjem sudske prakse, cjelovitijoj sistematizaciji te jasnijoj podjeli pravnih načela, načela i standarda "sveučilišnog prava i prava znanstvenih organizacija". Ako ne postoji odrediv broj pravnih načela i općeprihvaćeni kriterij(i) njihove sistematizacije, onda normativistički pristup nije dovoljan kako bi se na ta pitanja odgovorilo.

\section{LITERATURA}

Borković, I., Upravno pravo, Informator, Zagreb, 1995.

Dworkin, R., Shvaćanje prava ozbiljno, KruZak, Zagreb, 2003.

Fikentscher, W., Methoden des Rechts, J.C.B. Mohr (Paul Siebeck), Tübingen, 1976.

Grubišić, K., Normativne pretpostavke društva znanja, u: Afrić, V. et al. (ur.), Društvene pretpostavke društva znanja, FF press, Zagreb, 2011., str. 105-121.

Grubišić, K., Sistematizacija pravnih normi u visokom obrazovanju i znanosti u Republici Hrvatskoj, Zbornik Pravnog fakulteta u Zagrebu, vol. 67, br. 3-4, 2017., str. 565-599.

Guastini, R., Sintaksa prava, Breza, Zagreb, 2016.

Häberle, P., Ustavna država, Politička kultura, Zagreb, 2002.

Harris, J. W., Law and Legal Science, Oxford University Press, New York, 2007.

Ivančević, V., Institucije upravnog prava, Pravni fakultet Zagreb, Zagreb, 1983.

Kant, I., Kritik der reinen Vernunft I, Suhrkamp, Frankfurt am Main, 1997.

Kant, I., Metafizika ćudoređa, Matica Hrvatska, Zagreb, 1999.

Kant, I., Pravno-politički spisi, Politička kultura, Zagreb, 2000.

Kelsen, H., Čista teorija prava, Naklada Breza, Zagreb, 2012.

Kelsen, H., Opća teorija normi, Naklada Breza, Zagreb, 2015.

Liessmann, K. P., Teorija neobrazovanosti: zablude društva znanja, Naklada Jesenski i Turk, Zagreb, 2008.

Luhmann, N., Pravo društva, Naklada Breza, Zagreb, 2014.

MacCormick, N., Institutions of Law: An Essay in Legal Theory, Oxford University Press, New York, 2009.

Pavčnik, M., Teorija prava, Cankarjeva založba, Ljubljana, 2001.

Pavčnik, M., Teorija prava, GV Založba, Ljubljana, 2011. 
Radbruch, G., Filozofija prava, Naklada Breza, Zagreb, 2019.

Ruiter, D. W.P., Legal Institutions, Kluwer Academic Publishers, Dordrecht, 2010.

Smerdel, B.; Sokol, S., Ustavno pravo, Sveučilišna tiskara d.o.o., Zagreb, 2006.

USRH, Nacionalno izvješće:, Odgovori na upitnik za XVII. kongres Konferencije Europskih ustavnih sudova, Zagreb, 2016., dostupno na: https://www.usud.hr/ sites/default/files/dokumenti/Upitnik_i_tema_XVII._kongresa_Konferencije_europskih_ustavnih_sudova_odrzanog_u_Batumiju_Gruzija_od_28._lipnja_do_1._srpnja_2017.pdf\#page5

Visković, N., Teorija države i prava, Birotehnika CDO, Zagreb, 2001.

Visković, N., Teorija prava, Split, 1985.

\section{Pravni izvori}

Ustav Republike Hrvatske, Narodne novine br. 56/90, 135/97, 28/01, 76/10 i 5/14.

\section{Zakoni}

Zakonu o akademskim i stručnim nazivima i akademskom stupnju, Narodne novine, br. 107/07 i 118/12.

Zakonu o Hrvatskom kvalifikacijskom okviru Narodne novine, br. 22/13 i Odluka USRH, br. 4l/16.

Zakonu o Hrvatskoj zakladi za znanost Narodne novine, br. 117/01, 45/09, $92 / 10$ i $78 / 12$.

Zakonu o osiguravanju kvalitete u znanosti i visokom obrazovanju, Narodne novine, br. 45/09.

Zakonu o potvrđivanju konvencije o priznavanju visokoškolskih kvalifikacija u području Europe, Narodne novine - Međunarodni ugovori, br. 9/02 i 15/02.

Zakonu o priznavanju inozemnih obrazovnih kvalifikacija, Narodne novine, br. 158/03, 198/03, 138/06, 124/09, 45/11.

Zakonu o studentskom zboru i drugim studentskim organizacijama, Narodne novine, br. $71 / 2007$.

Zakon o visokim učilištima, Narodne novine, br. 59/96, 02/99, 14/00 i 26/00, 67/00, 94/00 i 129/00

Zakon o znanstvenoj djelatnosti i visokom obrazovanju, Narodne novine, br. 123/03., 105/04., 174/04., 2/07. - Odluka USRH, 46/07, 45/09, 63/11, 94/13 i 139/13, 101/14 - Odluka i Rješenje USRH, 60/15 - Odluka USRH, 131/17.

Kolektivni ugovor za znanost i visoko obrazovanje, Narodne novine br. 9/19. 


\section{Odluke i rješenja Ustavnog suda Republike Hrvatske}

Odluka i Rješenje Ustavnog suda Republike Hrvatske, br: U-I-902/1999 od 26. siječnja 2000., Narodne novine, br. 14/00, 26/00 - ispr.67/00.

Odluka Ustavnog suda Republike Hrvatske, br: U-I-843/2000 od 13. rujna 2000., Narodne novine, br. 94/00.

Rješenje Ustavnog suda Republike Hrvatske, br: U-I-1441/2001 od 23. listopada 2003., Narodne novine, br. 177/03.

Odluka Ustavnog suda Republike Hrvatske, br: U-I-1707/2006 od 20. prosinca 2006., Narodne novine, br. 2/07.

Odluka Ustavnog suda Republike Hrvatske, br: U-I-4585/2005, U-I-4799/2005, U-I-2446/2006 i U-I-3502/2006 od 20. prosinca 2006., Narodne novine, br. $2 / 07$.

Odluka Ustavnog suda Republike Hrvatske, br: U-II-1304/2013 od 16. srpnja 2013., Narodne novine, br. 99/13.

Odluka i Rješenje Ustavnog suda Republike Hrvatske, br: U-I-5578/2013 i U-I3633/2014 od 18. srpnja 2014., Narodne novine, br. 101/14.

Odluka Ustavnog suda Republike Hrvatske, br: U-I-35I/2016 od 20. travnja 2016., Narodne novine, br. 41/16.

Odluka Ustavnog suda Republike Hrvatske, br: U-II-625I/2016 od 25. travnja 2017., Narodne novine, br. 46/17.

Rješenje Ustavnog suda Republike Hrvatske br. U-I-1 102/2009 od 21. studenoga 2017. https://sljeme.usud.hr/usud/praksaw.nsf/vSignaturaPoGodiniRije.xsp

Rješenje Ustavnog suda Republike Hrvatske br. U-I-3416/2007 od 19. prosinca 2017. https://sljeme.usud.hr/usud/praksaw.nsf/vSignaturaPoGodiniRije.xsp

Rješenje Ustavnog suda Republike Hrvatske br. U-I-4613/2015 od 30. siječnja 2018. https://sljeme.usud.hr/usud/praksaw.nsf/vSignaturaPoGodiniRije.xsp

Rješenje Ustavnog suda Republike Hrvatske br. U-I-4981/2013 i U-I-1454/2014 od 9. listopada 2018. https://sljeme.usud.hr/usud/praksaw.nsf/vSignaturaPoGodiniRije.xsp 


\section{Summary}

\section{Ksenija Grubišić*}

\section{CRITERIA FOR DEFINING AND SYSTEMATIZING LEGAL PRINCIPLES IN HIGHER EDUCATION AND SCIENCE}

The aim of the paper is to investigate the criteria for a systematization and determination of the legal principles of "university law and the law of scientific organizations". In the research, the starting point is the two dichotomies of the legal system: the dichotomy of openness and closedness, and the dichotomy of the relationship between fact and value. Both dichotomies, presented in the context of different theoretical approaches, indicate the impossibility of defining generally accepted criteria not only for the systematization of legal principles, but also for their differentiation in relation to legal rules, as well as in relation to the principles and standards whose binding quality is often called into question both in theory and in practice.

Considering that an essential feature of legal principles is the mediation of fundamental values and a characteristic of substantive and numerical openness, the second part deals with the division of legal principles of "university law and the law of scientific organizations" with regard to the type of legal sources and the level of their normative concretization (explicit and implicit legal principles).

Keywords: guarantee of autonomy, dichotomy, explicit and implicit legal principles, normative concretization

* Ksenija Grubišić, Ph. D., Associate Professor, Faculty of Law, University of Zagreb, Trg Republike Hrvatske 14, Zagreb; ksenija.grubisic@pravo.hr;

ORCID ID: orcid.org/0000-0003-2464-1438 